\title{
Evaluation of Authentic Assessment Implementation in Public Elementary School 101775 Sampali, Deli Serdang Regency Academic Year 2019/2020
}

\author{
Syarifah Aini' ${ }^{1}$, Deny Setiawan ${ }^{2}, \operatorname{Siman}^{3}$ \\ Postgraduate Students of Basic Education Study Program \\ Medan State University (UNIMED) Medan, Indonesia \\ syarifahaini10@gmail.com
}

\begin{abstract}
This research is a type of evaluation research with a quantitative descriptive approach. The evaluation model used is the Stake Countenance Model. The subjects of this study were all teachers in Public Elementary School 101775 Sampali, Deli Serdang Regency with a total of 12 teachers. Data collection techniques using observation, questionnaires, documentation and interviews. In analyzing data using descriptive methods. From the results of research conducted on the evaluation of the implementation of authentic assessment in Public Elementary School 101775 Sampali Deli Serdang Regency with a stake count maintenance evaluation model of 90.39\%. This is evidenced from the three stages of stakeholder evaluation in the implementation of authentic assessment which consists of an input phase (Antecedents phase) which is evaluated consisting of analysis of learning documents, attitude assessment documents, knowledge assessment documents and skills assessment very well complete with a percentage of $89.46 \%$. In the transaction phase that was evaluated, namely how the authentic assessment carried out by the teachers at Public Elementary School 101775 Sampali was carried out very well with a percentage of $90.71 \%$. In the evaluated outcome phase which is the reporting of student learning outcomes and teacher understanding of the implementation of authentic assessment in schools has been going very well with a percentage of $91 \%$. The next suggestion for the implementation of authentic assessment is continuously monitored so that the teacher's understanding of the implementation of authentic assessment can be carried out properly.
\end{abstract}

Keywords: Evaluation; Authentic Assessment.

\section{Introduction}

Authentic assessment has a strong relevance to the scientific approach to learning in accordance with the demands of the 2013 curriculum. This is because this kind of assessment is able to illustrate the improvement in student learning outcomes, both in the context of observing, reasoning, trying, building networks and others.

Authentic assessment is often described as an assessment of students' development because it focuses on their developing ability to learn how to learn about the subject. Authentic assessment must be able to describe the attitudes, skills and knowledge of what students have or have not had, how they apply their knowledge, in what way they have or have not been able to apply learning acquisition, and so on.

Authentic assessment data is used for various purposes such as determining the feasibility of accountability for curriculum implementation and learning in certain classes. Authentic assessment data can be analyzed by qualitative and quantitative methods. Qualitative analysis of authentic assessment in the form of narration or description of student 
learning outcomes, such as strengths, weaknesses, motivation, courage to think, and so on. Quantitative analysis of authentic assessment data applies score rubrics or checklists to assess students' relative responses relative to criteria in a limited range of four or more skill levels, such as being very proficient, proficient, quite proficient and not proficient.

The application of authentic assessment in education is a very important aspect. The assessment functions to improve learning methods, measure students' readiness and provide information that can help educators in carrying out better education and in making decisions about the sustainability of studies and evaluations of learning programs. (Doso Warso, 146: 2011).

The success of students in their learning must be measured by measuring instruments that are in accordance with the learning objectives or competencies that must be achieved. The information obtained from the assessment must be comprehensive and have been carried out at the right times. Measurement, evaluation and evaluation have a very related relationship. Assessment is a process carried out through the steps of planning, preparation of assessment tools, and gathering information through a number of evidence that shows the achievement of student learning outcomes, management and use of information. The assessment is done before measurement, because measurement is giving numbers to objects or rules that give quantitative meaning (Muslich, 3: 2011).

Government education and culture No. 32 of 2013 said that the 2013 curriculum which was developed as a step to improve the previous curriculum was expected to be able to realize the National Education Goals. The steps to be taken include structuring the mindset and governance of the curriculum, deepening and expanding the material, strengthening the process, and adjusting the burden of teachers and students.

Evaluation is very much needed for the purpose of making educational policies for all elements of education involved in Public Elementary School 101775 Sampali Deli Serdang Regency. If it has been evaluated and identified obstacles and sought the most rational solution, the results of the study can serve as a reference for the smooth implementation of authentic assessment in the future. Therefore, this study is entitled Evaluation of the Implementation of Authentic Assessment in Public Elementary School 101775 Sampali, Deli Serdang Regency, Academic Year 2019/2020.

\section{Review of Literature}

\subsection{Definition of Authentic Assessment}

Authentic assessment (authentic assessment) is a stage of gathering, reporting and using information about student learning outcomes by implementing the principles of assessment, continuous implementation, authentic evidence, precise and consistent as public accountability. This is in line with Johnson's opinion that authentic assessment provides broad opportunities for students to show what has been learned and what has been mastered during the learning process.

According to Abdul Majid (2014: 56), authentic assessment (authentic assessment) is an activity that is rarely used in the assessment process, authentic assessment is more often expressed as a performance based assessment (Performance based assessment). Authentic 
assessment is often called performance appraisal or performance-based assessment, because in this assessment it directly measures students' actual performance in certain matters, students are asked to perform meaningful tasks using real world or authentic assignments or context.

In the attachment to Government education and culture No. 66 of 2013 concerning the assessment standards explained that the assessment of the learning process using authentic assessment that assesses student readiness, process and student learning outcomes as a whole. Authentic assessment results can be used by teachers to plan remedial, enrichment or counseling services. Authentic assessment results can also be used as material to improve the learning process in accordance with education assessment standards. Evaluation of the learning process is carried out during the learning process by using tools: questionnaires, observations, anecdotal notes, and reflections.

\subsection{Definition of evaluating the implementation of authentic assessment}

Authentic evaluation evaluations can be carried out in various stages. In the idea development stage, the stage of concept formulation, the stage of implementation / application, and the stage of results that have an impact on society. Evaluation activities can be carried out starting from the central level by the Ministry of Education and Culture to the implementing level by each education unit. Evaluation activities are important to be carried out in order to determine the implementation of authentic assessments that have been implemented.

In this study, the evaluation was carried out at the implementation stage of authentic assessment. The implementation of authentic assessment in Public Elementary School 101775 Sampali Deli Serdang Regency 2019/2020 Academic Year was carried out in 12 classes in the total number of classes in the school. The implementation of authentic assessment runs for one theme of the lesson. Evaluation is carried out to find out the extent of the implementation of authentic assessment and also to find out whether there are still obstacles encountered in the implementation of authentic assessment. Based on some of the explanations above it can be concluded that the evaluation of the implementation of authentic assessment is a process of gathering information data to find out the process and results of curriculum implementation that can be used to see the level of success and is used to make decisions in making corrective steps.

\subsection{Evaluation Model Stake Contenance}

Research on evaluating the implementation of authentic assessments at PUBLIC ELEMENTARY SCHOOL 101775 Sampali in Deli Serdang District using the Countenance Evaluation Model of Stake's Countenance Models (Stufflebearn, 1984: 146). The use of this type of evaluation model is based on making an evaluation of the program being evaluated. This type of evaluation is based on making an evaluation of the program being evaluated as well as the ease of categorizing data based on 3 phases, namely the dependent, transaction, and outcomes. Evaluation is done by comparing the data in the field with the standard so that a picture that shows the actual situation compared to the standard is obtained. This evaluation model also allows researchers to be able to give consideration without having to make 
decisions. Decision making can be done by other parties. Consideration is used as reference material for improving the implementation of authentic assessment in Public Elementary School 101775 Sampali Deli Serdang Regency in the academic year 2019/2020.

Worthen \& Sanders (1973: 112) describes evaluations that use the Stake Countenance models evaluation model consisting of 2 main matrices, which are the description matrix and the judgment matrix. Each matrix has 3 steps to differentiate data collected. The three stages are antecedent (preliminary), transaction (process), and outcomes (results). Antecedent is a condition that exists before learning that may be related to learning outcomes. Transactions are meetings between students and teachers, students and students, parents and counselors in the education process. Outcomes as information that includes measurements of the effects of learning by teachers, administrators, counselors, and others.

Stake (Ornstein \& Hunkins, 2009: 285) describes 3 categories of data; (a) Antecedent, that is, any conditions that exist before the teaching and learning process that can affect outcomes, (b) Transaction interactions that occur between students and teachers, students and teachers, and students and learning, (c) Outcomes are the results of programs / procedures.

Things that are antecedent include (a) the status or characteristics of students before the lesson eg: aptitude, previous achievement scores, psychological profiles, grades, discipline and attendance; (b) teacher characteristics such as teaching experience and teacher behavior rating. Transactions also include student interaction with curriculum material and the classroom environment. Transaction is a learning process. Furthermore, included Outcomes include student achievement, attitudes and motor skills; the impact of teacher perceptions on their competence and the effect of administrative actions.

Stake (Worthen \& Sanders, 1973: 114) explains that each matrix is further divided into 2 columns. The description matrix (description) is divided into 2 columns namely the intents column and the observations column. Judgment matrix is divided into 2 columns namely standard and judgment.

Intents in the description matrix are interpreted as the goals and objectives of the observation program are the results of observations / observations of the category of intents that are implemented in the field. Standards in the judgment matrix are defined as "benchmarks of performance having widespread reference value". Performance benchmarks that have broad reference values. The judgment column was developed by interpreting the difference between what has been observed with the standard.

\section{Research Method}

This research is an evaluative study with a quantitative approach. Evaluation of the implementation of authentic assessment was carried out at Public Elementary School 101775 Sampali in Deli Serdang Regency. This research was conducted using an evaluation model stake (Fernandes, 1984) which consists of three phases namely; input (antecedents) process (transaction) and results (outcomes). Each stage is divided into two stages, namely description (description) and decision (judgment). The implementation of the research for 1 month in the odd semester of the 2019/2020 academic year starting on August 19 to 
September 20 2019. The respondents in this study were teachers in Public Elementary School 101775 Sampali Deli Serdang Regency with a total of 12 people.

\section{Result}

\subsection{Evaluation of the Implementation of the Stake Model Authentic Assessment}

Teachers' understanding of how to carry out authentic assessments is highly demanded. In evaluating the implementation of authentic assessment research, researchers want to see how the understanding of teachers at Public Elementary School 101775 in understanding the implementation of authentic assessment at the school. On the results of data processing of teacher understanding of the implementation of authentic assessment in Public Elementary School 101775 Sampali about mastery of attitude assessment, knowledge assessment and skills assessment, processing the value of student learning outcomes and up to the reporting of student learning outcomes obtained an average score of 63.83 with a percentage $85.78 \%$. Therefore it can be concluded that the teacher's understanding of the implementation of authentic assessment in Public Elementary School 101775 Sampali is categorized as good.

\subsection{Evaluation of the Implementation of Authentic Assessment Input Phase}

The results of the data processing in the input phase show that the evaluation in the input phase (antecedents phase) of the analysis of learning documents and authentic assessment documents in Public Elementary School 101775 Sampali Deli Serdang District is going well. This can be seen from the evaluation of the input phase, namely the analysis of authentic assessment documents with an average score of 60.83 with a percentage of $89.46 \%$ included in either category.

Overall the analysis of learning documents and analysis of authentic assessment documents in the input phase (antecedents) conducted by the Public Elementary School 101775 Sampali Deli Serdang District teachers have been carried out well.

The ability of teachers in preparing learning documents ranging from syllabus, lesson plans, teaching media, teaching materials to LKPD is very good. This is due to supporting factors such as the availability of teacher manuals provided by the education office through schools or also some teachers downloading from the Ministry of Education and Culture page. In addition, learning documents are always monitored every month by the school principal. So that the teachers at Public Elementary School 101775 Sampali are accustomed to orderly in preparing learning documents and authentic assessment documents in their respective classes.

Besides that, the District Education Office also provides assistance and monitoring to schools in Deli Serdang Regency, including Public Elementary School 101775 Sampali, which is a school that is always monitored every month.

Data obtained from the field when compared with the standard of learning documents and authentic assessment documents that refer to the Basic and Secondary Education Process Standards based on Government of cultural education No. 222016 can be concluded that the analysis of authentic learning documents and assessments in Public Elementary School 
101775 Sampali Deli Serdang Regency is included in the very category well, it meets the standards of existing learning documents and authentic assessment documents.

\subsection{Evaluation of the Implementation of Authentic Process Phases}

The results of the data processing show that the components that have been evaluated in the transaction phase conducted by teachers at Public Elementary School 101775 Sampali, obtained an overview of the implementation of authentic assessment at the school. When you look at the percentage of evaluation results on the implementation of authentic assessment in each class, it can be seen that the average class teacher has performed an authentic assessment very well.

The development of indicators conducted by teachers in designing assessments has met the authentic assessment standards. Arranging instruments is very important in the assessment of student learning outcomes. By developing an appropriate assessment instrument, it will produce valid and accurate information on the achievement of students' competencies. The teacher has planned the type of assessment, assessment techniques, form of assessment well.

Overall, the authentic assessment in the process phase carried out by teachers at PUBLIC ELEMENTARY SCHOOL 101775 Sampali has been carried out very well, seen from the average score and percentage at the process phase which is $90.71 \%$ which is included in the very good category, in other words the teachers at Public Elementary School 101775 Sampali have been able to implement authentic assessments that have been designed or planned in their respective lesson plans very well.

Authentic assessment is carried out integrated in the learning process in the classroom. Authentic assessment is carried out during and after the learning process takes place. Evaluation of authentic assessment implementation in the transaction phase includes indicators that inform how the assessment system is in line with existing standards. The implementation of authentic assessment is carried out after the teaching and learning process.

Authentic assessment is carried out integrated in the learning process in the classroom. Authentic assessment is carried out during and after the learning process takes place. Evaluation of authentic assessment implementation in the transaction phase includes indicators that inform how the assessment system is in line with existing standards. The implementation of authentic assessment is carried out after the teaching and learning process.

\subsection{Evaluation of the Implementation of Authentic Assessment Results Phase}

The results of data processing indicate that the level of achievement of the evaluation of the implementation of authentic assessment in the observation phase conducted by teachers in Public Elementary School 101775 Sampali obtained an average value of 32.58 with a percentage of $91 \%$. It can be concluded that the evaluation of the implementation of the results phase conducted by teachers of Public Elementary School 101775 Sampali is in the very good category.

Results evaluation activities are efforts to measure and interpret or the results achieved from a program. The results of the assessment by the teacher using various instruments need 
to be processed to find a picture of the achievement of the ability of students after learning in class.

Value processing consists of the results of the assessment of three aspects, namely attitude assessment, knowledge assessment and skills assessment. The processing and followup of authentic assessment in learning at Public Elementary School 101775 Sampali is going very well. When compared with the standard processing of values and the follow-up of authentic assessment is sufficient to meet these standards.

\subsection{Evaluation of the Implementation of Authentic Assessment of Stake Countenance Model}

\begin{tabular}{|c|c|c|c|c|}
\hline No & $\begin{array}{l}\text { Evaluation Phase of } \\
\text { Authentic Assessment }\end{array}$ & $\begin{array}{c}\begin{array}{c}\text { Average Value } \\
\text { of Evaluation } \\
\text { Results }\end{array} \\
\end{array}$ & $\begin{array}{c}\text { Percentage } \\
(\%)\end{array}$ & Category \\
\hline 1 & Input Phase (Antecedents) & 60.83 & $89.46 \%$ & Good \\
\hline 2 & Process Phase (Transactions) & 39.91 & $90.71 \%$ & Very Good \\
\hline 3 & Results Phase (Outcomes) & 32.58 & $91 \%$ & Very Good \\
\hline & Total & \multirow{2}{*}{133.32} & 271.17 & \multirow{2}{*}{ Very Gooc } \\
\hline & Average Score & & $90.39 \%$ & \\
\hline
\end{tabular}

Results Phase From the results of research conducted by researchers on the evaluation of the implementation of authentic assessment in Public Elementary School 101775 Sampali Deli Serdang Regency by using the stake countenance model as a whole was implemented well with a percentage of $90.39 \%$. Very good criteria in the implementation of authentic assessment shows that the implementation of authentic assessment in Public Elementary School 101775 Sampali is in accordance with the standard of authentic assessment that refers to Government of cultural education Number 66 of 2013 and Government of cultural education number 104 of 2014 concerning assessment standards.

This can be seen from the three stakeholder evaluations on the implementation of authentic assessment which consists of the input phase (Antecedents phase), the process phase (transaction phase) and the results phase (outcomes phase). Authentic assessment or direct and comprehensive overall assessment that emphasizes the realm of attitude, knowledge and skills assessment.

\section{Conclusion}

Based on the results of research and discussion on evaluating the implementation of authentic assessment at Public Elementary School 101775 Sampali Deli Serdang Regency, the following conclusions are obtained:

1. The implementation of authentic assessment in Public Elementary School 101775

Sampali was carried out very well as seen from the percentage of authentic evaluation evaluations of the stakeholder model that is $90.39 \%$. This is evidenced from the three stages of stakeholder evaluation in the implementation of authentic assessment which 
consists of the input phase (Antecedents phase) which is evaluated consisting of analysis of learning documents, attitude assessment documents, knowledge assessment documents and skills assessment very well complete with a percentage of $89.46 \%$. In the transaction phase that was evaluated, namely how the authentic assessment carried out by the teachers at Public Elementary School 101775 Sampali was carried out very well with a percentage of $90.71 \%$. In the evaluated outcome phase which is the reporting of student learning outcomes and teacher understanding of the implementation of authentic assessment in schools has been going very well with a percentage of $91 \%$.

2. The obstacle in authentic assessment experienced by teachers is the lack of understanding of some teachers about authentic assessment, the many components that must be considered simultaneously in the process of authentic assessment, when evaluating teacher attitudes must assess as much detail as possible the behavior and attitudes of students as a whole while the number students in the classroom are generally still very many and teachers are still often overwhelmed by the value of student learning outcomes.

\section{References}

Fernandes, H.J.X. (1984). Evaluation educational of program. Jakarta: National Education planning evaluation and curriculum development.

Kunandar. (2013). Penilaian Autentik (Penilaian Hasil Belajar Peserta Didik Berdasarkan Kurikulum 2013). Jakarta: Raja Grafindo Persada.

Majid, Abdul. 2014. Penilaian Autentik Proses dan Hasil Belajar. Bandung: PT Remaja Rosdakarya.

Mansur, Muslich. (2011). Autentik Assessment: Penilaian Berbasis Kelas dan Kompetensi. Bandung: Refika Aditama.

Ornstein, A.C \& Hunkins F.P. (2009). Curriculum: Foundation, Principles and Issues. Boston: Pearson Education, Inc.

Peraturan Menteri Pendidikan dan Kebudayaan Republik Indonesia No. 66 tahun (2013) tentang Standar Penilaian. Jakarta: Kementrian Pendidikan dan Kebudayaan.

Stufflebearn. D. (1999). Foundational Model For 21st Century Program Evaluation In Symposiom at The Annual Meeting of The American Educational Reasearch Association (p. 11). Montreal, Quebec: Canada.

Wasisto, Agus Dwi Doso Warso. (2011). Proses Pembelajaran dan Penilaiannya di SD/ MI/ SMP/MTs/SMA/MA/ SMK Sesuai Kurikulum 2013. Yogyakarta: Graha Cendekia

Worthen. B.R \& Sanders. J.R. (1973). Educational evaluation: Theory and Practice. Worthington: Charles A Jones Publishing company. 